\title{
PENGARUH KEBIASAAN MEMBACA BERITA TERHADAP KETERAMPILAN BERFIKIR KRITIS PADA PESERTA DIDIK SMA NEGERI DI KOTA LANGSA
}

\author{
Wika Barokah ${ }^{1}$, Nadia Kesuma ${ }^{2}$ \\ Program Studi Pendidikan Geografi, FKIP, Universitas Samudra, Langsa, Indonesia \\ ${ }^{1}$ wikabarokah12@gmail.com, ${ }^{2}$ nadiakesuma01@gmail.com
}

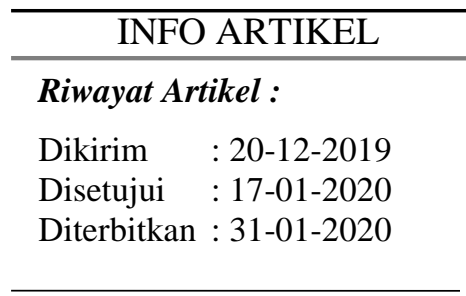

Kata Kunci :

Keterampilan Berfikir Kritis, Membaca Berita, Peserta Didik SMA

\section{ABSTRAK}

The purpose of this study was to analyze the regression relationship between the News Reading Habits of Critical Thinking Skills of high school students. The method used in this research is Survey Method. Field trial subjects with respondents were students of SMA NEGERI in Langsa City, using the random stratified sampling technique used. This data was analyzed using IBM SPSS Statistics 23 through linear regression analysis. The results of this study state that the habit of reading news influences students' critical thinking skills. This result is stated by t-test which has a significance value of .003. With proven influence on the habit of reading news on critical thinking skills, the researcher recommends to the readers, especially the teacher to direct and welcome the interests and habits of reading news to students.

Tujuan dari penelitian ini adalah untuk menganalisis hubungan regresi antara Kebiasaan Membaca Berita Terhadap Keterampilan Berfikir Kritis peserta didik SMA. Metode yang digunakan di dalam penelitian ini yaitu Metode Survei. Subjek uji coba lapangan dengan para responden yaitu siswa/i SMA NEGERI di Kota Langsa, dengan teknik random stratified sampling yang digunakan. Data ini dianalisis dengan menggunakan IBM SPSS Statistics 23 melalui analisis regresi linier. Hasil penelitian ini menyatakan bahwa kebiasaan membaca berita berpengaruh terhadap keterampilan berpikir kritis siswa. Hasil ini dinyatakan dengan uji-t yang memiliki nilai signifikansi sebesar, 003. Dengan terbukti berpengaruhnya kebiasaan membaca berita terhadap keterampilan berfikir kritis, maka peneliti merekomendasikan kepada para pembaca, khususnya Guru untuk mengarahkan dan menyongsong minat serta kebiasaan membaca berita terhadap peserta didik.

\section{PENDAHULUAN}

Survey UNESCO menyebutkan bahwa persentase minat membaca anak di Indonesia masih rendah. Hanya 1 dari 10.000 anak saja yang memiliki minat untuk membaca (Damanik, 2015). Padahal membaca merupakan jembatan ilmu pengetahuan, dengan membaca kita dapat memperoleh informasi dan ilmu pengetahuan. Kurangnya minat membaca berpengaruh terhadap kualitas dalam pencapaian hasil belajar yang diraih oleh peserta didik. Padahal guru telah menerapkan literasi sebelum memulai pembelajaran, tetapi realita nya banyak siswa yang tidak menerapkannya dengan baik. Membaca buku materi pelajaran yang memang sudah menjadi pokok utama seorang peserta didik, tetapi mereka tidak menjalankan dengan semestinya, apalagi lagi membaca berita yang menjadi ladang informasi dan ilmu pengetahuan kedua setelah buku. Maka penelitian ini sangat penting dilakukan untuk mengetahui tingkat minat membaca berita yang dapat berpengaruh terhadap keterampilan berfikir kritis. 


\section{Keterampilan berpikir kritis merupakan hasil dari pemikiran yang mendalam untuk memfokuskan terhadap apa yang diyakini dan tindakan yang dilakukan ketika menghadapi suatu masalah. (Syarifah \& Sumardi, 2015). Pengertian lain nya Berpikir \\ coba lapangan para responden yaitu peserta didik SMA Negeri di Kota Langsa. Penelitian ini menggunakan Random Stratified Sampling dengan menggunakan Observasi berupa Penyebaran Angket kepada para Siswa/i SMA di Kota Langsa.} kritis adalah penggunaan intelegensi dalam membuat keputusan, kemampuan ini terbentuk melalui proses perkembangan (Anggraeni, 2012). Berpikir kritis berkaitan dengan keahlian berpikir induktif, seperti mengetahui hubungan, menganalisis masalah yang dapat diketahui atau bersifat terbuka, membedakan sebab dan akibat, menarik kesimpulan dan menganalisis data yang relevan. Sedangkan keahlian berpikir deduktif berhubungan dengan kemampuan memecahkan masalah yang bersifat logis, spasial dan dapat membedakan antara fakta dan opini. Kemampuan berpikir kritis lainnya meliputi kemampuan melakukan evaluasi, membandingkan dan mendeteksi bias (Kusumah, 2019). Maka melalui berpikir kritis kita juga dapat memecahkan sejumlah persoalan dengan mencari jawaban yang tepat. Membaca berita dapat memicu seseorang untuk berfikir kritis. Dengan begitu ia dapat dengan mudah memiliki alternatif solusi dalam memecahkan dan mengatasi suatu masalah.

Sebelumnya penelitian ini belum pernah diteliti oleh siapapun, tetapi sudah banyak yang meneliti hanya tentang keterampilan berfikir kritis yang dapat dipicu melalui hal lain seperti, Pengaruh Model Discovery Learning, Penerapan Model Problem Based Learning, Pendekatan Matematika Realistik (PMR) yang juga dapat mempengaruhi dan memicu keterampilan berfikir kritis. Tujuan dari penelitian ini yaitu untuk menganalisis hubungan regresi antara Kebiasaan Membaca Berita Terhadap Keterampilan Berfikir Kritis. Selain itu untuk mengetahui benar tidaknya membaca berita dapat berpengaruh terhadap keterampilan berfikir kritis.

\section{METODE PENELITIAN}

Didasarkan pada tujuan penelitian metode penelitian yang digunakan yaitu Metode Survei.

Penelitian metode survey yaitu teknik pengumpulan data atau informasi dengan cara membuat susunan pertanyaan yang akan diajukan kepada responden. Dengan subjek uji

\section{HASIL DAN PEMBAHASAN}

Hasil penelitian yang dianalisis menggunakan software IBM SPSS 23 dapat dilihat pada tabel 1 dan tabel 2.

Berdasarkan tabel 1 , nilai $\mathrm{R}^{2}$ adalah 0.123. Data ini menunjukkan bahwa variable membaca berita berpengaruh sebesar 12,3\% terhadap keterampilan berfikir kritis.

Hasil penelitian ini dinyatakan dengan uji-t yang memiliki nilai signifikansi sebesar, 003. Dengan hasil penelitian tersebut, maka dapat dinyatakan bahwa kebiasaan membaca berita dapat mempengaruhi keterampilan berfikir kritis.

Keterampilan berfikir kritis dapat dipicu dan digali melalui membaca berita. Dengan membiasakan membaca berita dapat memperoleh wawasan dan pengetahuan lebih luas. Dimana suatu ilmu dan pengetahuan tidak hanya diperoleh dari guru saja, siswa tidak hanya menerima suatu ilmu pengetahuan dari seorang guru, tetapi dapat juga diperoleh dari membaca berita.

Saat membaca berita perlu adanya pemilihan, analisis dan penerjemahan dari berita yang dibaca, sehingga dapat memilah dan membedakan antara berita palsu dengan berita fakta. Dalam asumsi ini dapat dikaitkan bahwa keterampilan berfikir kritis mampu membedakan mengenai persoalan fakta dan opini suatu problem atau masalah.

Berdasarkan hasil survey yang dilakukan, dari 70 orang responden siswa/i di Kota Langsa 51 dari 70 orang yang memiliki minat atau sering membaca berita. Maka dapat disimpulkan bahwa siswa/i di kota Langsa memiliki minat membaca berita yang cukup tinggi, hanya saja perlu adanya pengarahan dan penggalakan yang dilakukan oleh pihak guru maupun lembaga pendidikan atau pihak sekolah.

Di Era Revolusi Industri 4.0 semakin meningkatkan Kemajuan Teknologi Informasi dan Komunikasi, menjadikan Smartphone tidak lagi hanya sebatas suatu kebutuhan sampingan atau tersier, tetapi sudah menjadi kebutuhan 
pokok bagi kalangan masyarakat millennial. Dengan demikian dilihat dari keterjangkauan dalam memperoleh berita, para siswa/i lebih tertarik mencari dan membaca berita melalui Smartphone dari pada membaca berita melalui media cetak berupa Koran, majalah, dan lainlain.

Dengan adanya minat siswa yang cukup tinggi dalam membaca berita berpengaruh terhadap keterampilan berfikir kritis siswa, maka ketika dalam menghadapi suatu kesulitan di dalam proses pembelajaran ataupun pada lingkungan sekolah, siswa dapat mengatasi dan menyelesaikan masalah tersebut. Selain itu siswa juga memiliki wawasan, informasi, pengetahuan dan memiliki banyak kosa kata atau perbendaharaan kata.

Tabel 1. Model Summary

\begin{tabular}{|c|c|c|c|c|}
\hline Model & R & R Square & $\begin{array}{c}\text { Adjusted R } \\
\text { Square }\end{array}$ & $\begin{array}{c}\text { Std. Error of the } \\
\text { Estimate }\end{array}$ \\
\hline 1 & $0.351^{\mathrm{a}}$ & 0.123 & 110 & 1.13574 \\
\hline
\end{tabular}

a. Predictors: (Constant). Membaca berita

Tabel 2. Coefficients ${ }^{a}$

\begin{tabular}{|c|c|c|c|c|c|c|}
\hline \multirow{2}{*}{ Model } & \multicolumn{2}{|c|}{$\begin{array}{c}\text { Unstandardized } \\
\text { Coefficients }\end{array}$} & $\begin{array}{c}\text { Standardized } \\
\text { Coefficients }\end{array}$ & \multirow{2}{*}{ t } & \multirow{2}{*}{ Sig. } \\
\cline { 3 - 5 } & B & Std. Error & Beta & & \\
\hline \multirow{2}{*}{1} & (Constant) & -0.812 & 0.921 & & -0.881 & 0.381 \\
\cline { 2 - 6 } & $\begin{array}{c}\text { Membaca } \\
\text { Berita }\end{array}$ & 0.079 & 0.026 & 0.351 & 3.086 & 0.003 \\
\hline
\end{tabular}

a. Dependent Variable: Berfikir Kritis

\section{SIMPULAN}

Dari hasil penelitian di atas, maka dapat disimpulkan bahwa terdapat hubungan positif antara kebiasaan membaca berita (X) dengan keterampilan berpikir kritis siswa (Y). Hal ini dinyatakan dengan uji $\mathrm{t}$ yang memiliki nilai signifikansi sebesar, 003. Selain membaca buku, berfikir kritis mampu diasah melalui membaca berita. Berfikir kritis dapat membuat seseorang dalam mencari solusi dari suatu masalah, serta mampu membedakan antara fakta dan opini. Siswa yang gemar membaca berita memiliki pengetahuan dan wawasan yang luas serta mengetahui informasi terkini.

\section{REKOMENDASI}

Dengan menunjukkan bahwasanya membaca berita berpengaruh terhadap keterampilan berfikir kritis, maka peneliti merekomendasikan beberapa hal bagi guru, siswa dan lembaga pendidikan yaitu para pembaca, khususnya Guru untuk menumbuhkan dan mengarahkan minat serta kebiasaan membaca berita terhadap peserta didik, Perlu adanya peningkatan minat membaca berita agar menumbuhkan keterampilan berfikir kritis, pengetahuan dan wawasan serta mengetahui informasi terkini maka perlu adanya dukungan dari berbagai pihak terutama terjalinnya kerjasama yang melibatkan antara siswa, guru dan lembaga pendidikan.

\section{DAFTAR PUSTAKA}

Anggraeni, L. (2012). Penerapan Metode Studi Kasus Dalam Upaya Meningkatkan Kemampuan Berpikir Kritis Mahasiswa Pada Mata Kuliah Hubungan Internasional. Media Komunikasi FIS, 11(1), 15.

Ashraf, H., Garmabi, H., \& Fayendari, M. B. (n.d.). Do Critical Thinking Skills Lead to Success in Language Teaching? A Case of Iranian EFL Teachers Based on Their Gender and Degree of Education. 12. 
Bedir, H. (2016). Young Adolescent Efl Learners' Perspectives On Critical Thinking Skills. International Online Journal of Education and Teaching (IOJET), 3(3), 11.

Boa, E. A., Wattanatorn, A., \& Tagong, K. (2018). The Development And Validation Of The Blended Socratic Method Of Teaching (BSMT): An Instructional Model To Enhance Critical Thinking Skills Of Undergraduate Business Students. Kasetsart Journal of Social Sciences, 39(1), 81-89. https://doi.org/10.1016/j.kjss.2018. 01.001

Damanik. (2015). Pengaruh Model Discovery Learning Dengan Sisipan Membaca Kritis Terhadap Kemampuan Berpikir Kritis Siswa. EDUSAINS, $8(1)$. https://doi.org/10.15408/es.v8i1.17 52

Ikhsan, M., Munzir, S., \& Fitria, L. (2017). Kemampuan Berpikir Kritis dan Metakognisi Siswa dalam Menyelesaikan Masalah Matematika melalui Pendekatan Problem Solving. AKSIOMA: Jurnal Program Studi Pendidikan Matematika, 6(2), 234. https://doi.org/10.24127/ajpm.v6i2. 991

Ismaimuza, D. (2013). Kemampuan Berpikir Kritis dan Kreatif Matematis Siswa SMP Melalui Pembelajaran Berbasis Masalah dengan Strategi Konflik Kognitif. Jurnal Teknologi, 63(2). https://doi.org/10.11113/jt.v63.200 2

Khonamri, F., \& Farzanegan, M. (2016). Literature-Based Extensive Reading Accompanied By Reading Logs: A Case For Developing Critical Thinking Skills Of English Literature Students. International Journal of Education, 9(1), 56. https://doi.org/10.17509/ije.v9i1.37 19

Kusumah, R. G. T. (2019). Peningkatan Kemampuan Berfikir Kritis Mahasiswa Tadris IPA Melalui Pendekatan Saintifik Pada Mata kuliah IPA Terpadu. IJIS Edu: Indonesian Journal of Integrated Science Education, 1(1), 71. https://doi.org/10.29300/ijisedu.v1i 1.1762

Mart, C. (2016). Employability Skills among Students and Employers' Perceptions: An Assessment of Levels of Employability Skills Acquired by Business Students at Ishik University. International Journal of Social Sciences, 3(2), 13. Mulyana, T. (2009). Pembelajaran Analitik Sintetik untuk Meningkatkan Kemampuan Berpikir Kritis dan Kreatif Matematik Siswa SMA. Educationist, 3(1), 6.

Muttaqiin, A., \& Sopandi, W. (2016). Pengaruh Model Discovery Learning Dengan Sisipan Membaca Kritis Terhadap Kemampuan Berpikir Kritis Siswa. EDUSAINS, 8(1), 57-65. https://doi.org/10.15408/es.v8i1.17 52

Rachmadtullah, R. (2015). Kemampuan Berpikir Kritis Dan Konsep Diri Dengan Hasil Belajar Pendidikan Kewarganegaraan Siswa Kelas V Sekolah Dasar. Jurnal Pendidikan Dasar, $\quad 6(2), \quad 287$. https://doi.org/10.21009/JPD.062.1 0

Rachmawati, D., \& Rohaeti, E. (2018). Pengaruh Model Pembelajaran Sains, Teknologi, dan Masyarakat Terhadap Kemampuan Berpikir Kritis dan Motivasi Belajar Peserta Didik. Jurnal Pendidikan Matematika dan Sains, 6(1), 11.

Rani, A. R., \& Syukur, Y. (2019). Pengembangan Lembaran Kerja Peserta Didik Dengan Model 
Problem Based Learning Pada Siswa Kelas IV Sekolah Dasar. 3(2), 7.

Rosana, L. N. (2017). Pengaruh Metode Pembelajaran dan Kemampuan Berpikir Kritis Terhadap Hasil Belajar Sejarah Siswa. Jurnal Pendidikan Sejarah, 3(1), 34. https://doi.org/10.21009/JPS.031.0 4

Sari, T. P., \& Andajani, K. (2019). Hubungan Kemampuan Berpikir Kritis dengan Kemampuan Menulis Teks Editorial Siswa Kelas XII. Jurnal Pendidikan: Teori, Penelitian, dan Pengembangan, 4(1), 5.

Setyorini, U., Sukiswo, S. E., \& Subali, B. (2011). Penerapan Model Problem Based Learning Untuk Meningkatkan Kemampuan Berpikir Kritis Siswa SMP. Jurnal Pendidikan Fisika Indonesia, 7, 5.

Soviawati, E. (2011). Pendekatan Matematika Realistik (Pmr) Untuk Meningkatkan Kemampuan Berfikir Siswa Di Tingkat Sekolah Dasar. (2), 7.

Sumarmo, U., Hidayat, W., Zukarnaen, R., Hamidah, M., \& Sariningsih, R.
(2012). Kemampuan Dan Disposisi Berpikir Logis, Kritis, Dan Kreatif Matematik (Eksperimen Terhadap Siswa SMA Menggunakan Pembelajaran Berbasis Masalah Dan Strategi Think-Talk-Write). Jurnal Pengajaran Matematika dan Ilmu Pengetahuan Alam, 17(1), 17. https://doi.org/10.18269/jpmipa.v1 7i1.228

Sutrisno, F. H., Handayanto, S. K., Supriyana, E., \& Laksmisari, R. (2018). How Does The Students' Critical Thinking Ability In Geometry Optics. Unnes Science Education Journal, 7(2). https://doi.org/10.15294/usej.v7i2. 24297

Syarifah, S., \& Sumardi, Y. (2015). Pengembangan Model Pembelajaran Malcolm's Modeling Untuk Meningkatkan Keterampilan Berpikir Kritis Dan Motivasi Belajar Siswa. Jurnal Inovasi Pendidikan IPA, I(2), 237. https://doi.org/10.21831/jipi.v1i2.7 510 